\title{
To Teach is to Learn Twice: The Power of a Blended Peer Mentoring Approach
}

Followed by Student Response by Steven Prediger

\section{ABSTRACT}

Two students at a Canadian university perceived there was a lack of opportunities for peer mentoring support in their teacher education program. They approached a faculty member to co-create and research a blended peer mentoring support program embedded in a first-year education course. This study documents the journey of these two students as co-inquirers in a Scholarship of Teaching and Learning (SoTL) project. Through online surveys and interviews, first-year teacher candidates and faculty involved in the blended peer mentoring program identified four key benefits: new perspectives and expansion of ideas, positive and encouraging reinforcement, supportive connection with second-year students, and probing questions to think more deeply. Conversely, three major challenges were uncovered with the use of digital technologies to support this blended approach to peer mentoring: lack of email notification from the institution's learning management system (LMS) with regards to the peer mentors' online contributions, the impersonal nature of online peer mentoring, and the limited number of peer mentors. The major recommendation from this study was to create a blended program assignment to provide all second-year teacher candidates with the opportunity to learn how to serve as peer mentors to students just entering the teacher education program.

\section{KEYWORDS}

peer mentoring, facilitation, assessment, environment, professional responsibilities

\section{INTRODUCTION}

As undergraduate students at Mount Royal University (Canada), we (Kayla and Naomi) perceived there was a lack of opportunities for peer mentoring support in our teacher education program. We approached Norm, one of our faculty members, to co-create and research a blended second-year peer mentoring support program embedded in a first-year education course. In the spirit of Werder, Thibou, and Kaufer's (2012) work on the transformational potential of having students as coinquirers in the Scholarship of Teaching and Learning (SoTL), this study documents our journey of coinvestigating the impact of a blended peer mentoring support program.

Although the transition to teacher education programs at university can be a major hurdle for many, the educational research suggests peer mentoring support can help pre-service education students become more connected to the institution and their academic studies (Heirdsfield, Walker, Walsh, \& Wilss, 2008; Le Cornu, 2007). Many of these programs have been guided by Vygotsky's (1978) concept of a zone of proximal development (ZPD), defined as "the distance between the actual developmental 
level as determined by independent problem solving and the level of potential development as determined through problem solving under adult guidance, or in collaboration with more capable peers" (Vygotsky, 1978, p. 86). Vygostky viewed interaction with peers as an effective way of co-developing skills and strategies. Collins, Brown, and Holum's (1991) cognitive apprenticeship model has also been applied to these types of programs. This model consists of six components: modeling, coaching, scaffolding, articulation, reflection, and exploration. Nora and Crisp (2007) have built on the work of Vygotsky and Collins, Brown, and Holum to demonstrate how peer mentoring can provide four key constructs for university students: psychological/emotional support, support for setting goals and a career path, academic subject knowledge support aimed at advancing a student's knowledge relevant to her chosen field, and specification of a role model.

In terms of the benefits of peer mentoring for education students striving to become future $\mathrm{K}$ to 12 teachers, Friesen (2009) emphasizes that "teachers improve their practice in the company of their peers" (p. 6), and a recent Alberta Education (2014) report advocates that an effective teacher "collaborates to enhance teaching and learning" (n.p). Historically, Joubert stated in 1842 that "to teach is to learn twice" (Calvert, 1867), and Hattie (2009) stresses that visible learning takes place "when teachers SEE learning through the eyes of their students and students SEE themselves as their own teachers" (p. 238). This idea of reciprocal teaching and learning is grounded in the Mãori concept of ako, which means both to teach and to learn. It recognizes the knowledge both teachers and students bring to learning interactions, and acknowledges the way new knowledge and understandings can grow out of shared learning experiences (Alton-Lee, 2003).

Unfortunately, one of the key challenges of a peer mentoring approach in teacher education programs has been the difficulty for students to meet face-to-face outside of the classroom. Students in a previous study indicated that conflicting class schedules and the competing demands of part-time jobs, commuting, and family life provide limited opportunities for students to meet on campus (Vaughan, Nickle, Silovs, \& Zimmer, 2011). Our study investigated how a blended learning approach — the "organic integration of thoughtfully selected and complementary face-to-face and online approaches and technologies" (Garrison \& Vaughan, 2008, p. 148) — could address this peer mentoring challenge through the use of collaborative technologies (e.g., Google Applications).

\section{GUIDING FRAMEWORK}

Educational research studies related to the National Survey of Student Engagement (NSSE) have demonstrated the high impact of peer mentoring programs on student success and engagement (Kilgo, Sheets \& Pascarella, 2013). Developed in 1998 as a "lens to probe the quality of the student learning experience at American colleges and universities" (NSSE, 2011, p. 3), NSSE defines student engagement as the amount of time and effort that students put into their classroom studies that lead to experiences and outcomes that constitute student success, with specific attention to the ways the institution allocates resources and organizes learning opportunities and services to induce students to participate in and benefit from such activities. These conceptions of student engagement in higher education are grounded in several decades of prior research and particularly in four key antecedents:

1. Pace's (1980) emphasis on the quality of effort students put into their academic studies, rather than quantity.

2. Astin's (1984) theory of the importance of student involvement both inside and outside of the classroom.

3. Chickering and Gamson's (1999) seven principles of good practice in undergraduate education with a focus on active learning. 
4. Pascarella and Terenzini's (2005) theory of learning and development based on the effect of a students' background, pre-college characteristics, and the organizational features of a higher education institution.

Based on this research and a meta-analysis of the literature related to student engagement, NSSE identifies five clusters of effective educational practice. These benchmarks are as follows:

1. Student interactions with faculty members.

2. Active and collaborative learning.

3. Level of academic challenge.

4. Enriching educational experiences.

5. Supportive campus environment.

For the purposes of this study, the active and collaborative learning benchmark is the most relevant, as it relates directly to peer mentoring. In a previous study (Vaughan et al., 2013), first-year Bachelor of Education (B.Ed.) students who completed the NSSE at our university reported relatively high levels of active and collaborative learning, with the exception of tutoring or teaching other students (Table 1).

Table 1. First-year B.Ed. students' responses to active and collaborative learning NSSE Questions

\begin{tabular}{l|l|l}
\hline QUESTION & $\begin{array}{l}\text { STUDENT } \\
\text { RESPONSE } \\
\text { MARCH 2012 } \\
\text { OFTEN/VERY } \\
\text { OFTEN }\end{array}$ & $\begin{array}{l}\text { STUDENT } \\
\text { RESPONSE } \\
\text { MARCH 2013 } \\
\text { OFTEN/VERY } \\
\text { OFTEN }\end{array}$ \\
\hline Make a class presentation & $72 \%$ & $63 \%$ \\
\hline Work with other students on projects DURING class & $70 \%$ & $61 \%$ \\
\hline Ask questions in class or contribute to class discussions & $64 \%$ & $66 \%$ \\
\hline $\begin{array}{l}\text { Discuss ideas from your readings or classes with others outside of class } \\
\text { (students, family members, co-workers, etc.) }\end{array}$ & $60 \%$ & $57 \%$ \\
\hline Work with classmates OUTSIDE of class to prepare class assignments & $57 \%$ & $51 \%$ \\
\hline $\begin{array}{l}\text { Participate in a community-based project as part of a regular course } \\
\text { Tutor or teach other students } \\
\text { (paid or voluntary) }\end{array}$ & $53 \%$ & $31 \%$ \\
\hline
\end{tabular}

This data documenting the infrequent nature of tutoring or teaching other students helped validate our perception of a lack of peer mentoring opportunities in our teacher education program. This gap is of particular concern for our B.Ed. program, as this type of experience is critical for the growth and development of future teachers.

\section{STUDY CONTEXT}

Mount Royal University is a four-year undergraduate institution located in Calgary, Alberta, Canada (Figure 1). In the fall of 2011, a new Bachelor of Education program was launched as a four-year direct entry B.Ed. degree with program learning outcomes in five competencies areas: 
1. Planning

2. Facilitation

3. Assessment

4. Classroom environment

5. Professional roles and responsibilities.

In order to help the education students achieve these learning outcomes, the program emphasizes connecting theory with practice through early, consistent, and on-going field experiences. In the first two years of the program, students have a core education course each semester that meets once a week and is linked to a twenty- or thirty-hour field placement. In the third and fourth years of the program, the students have extended field placements that are connected to program-of-study courses and a capstone experience designed to integrate the theory of the coursework and the practice of the field experience. Despite this theory-to-practice connection, however, student feedback points to a lack of peer mentoring taking place in the program (Vaughan et al., 2013). Following graduation, the majority of students are hired as teachers in local $\mathrm{K}$ to 12 schools.

\section{Figure 1. Mount Royal University, Calgary, Alberta, Canada}

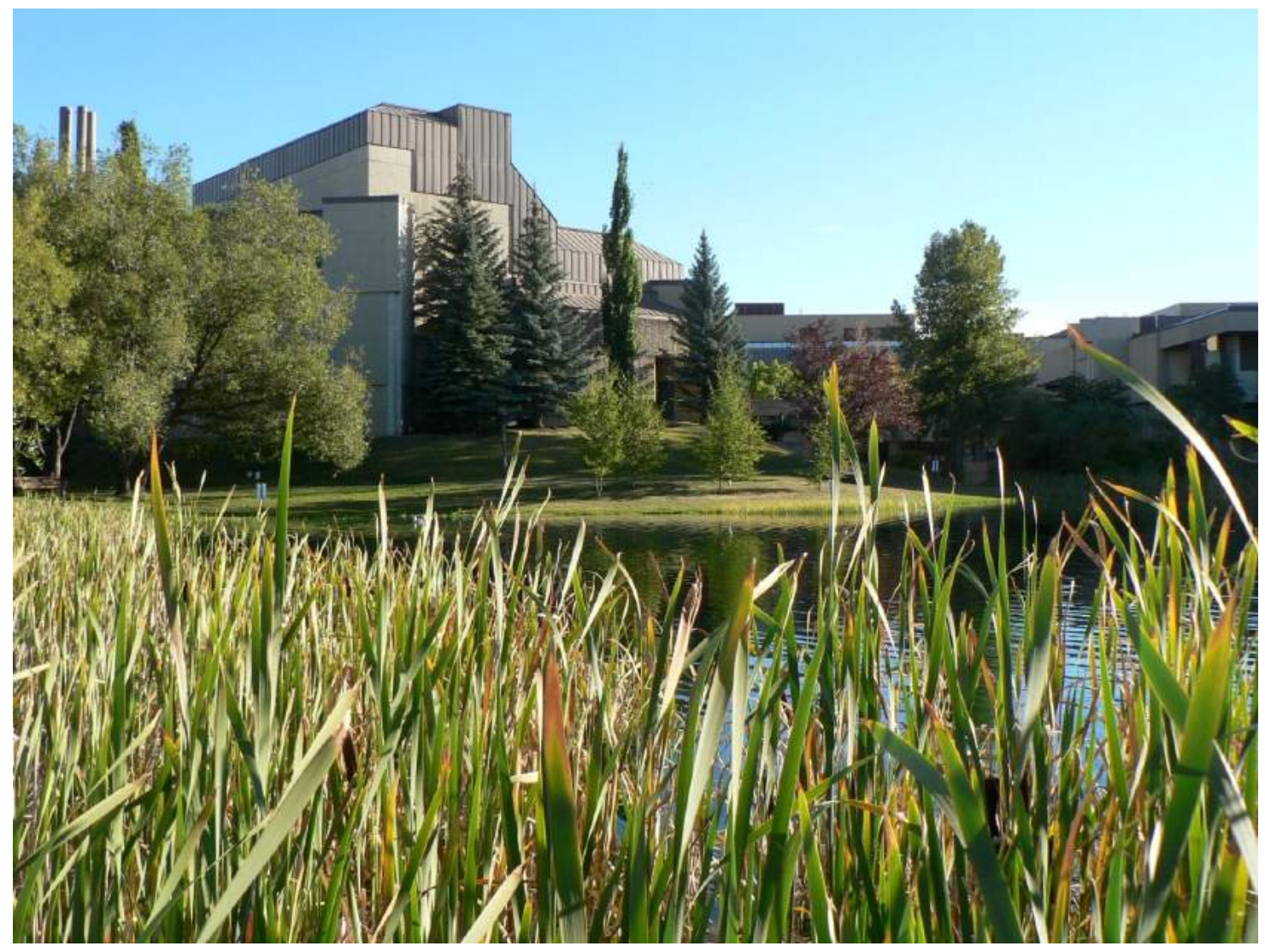

\section{METHODS OF INVESTIGATION}

To guide our peer mentoring study, we used a SoTL approach based on Felten's (2013) five principles of good practice:

1. Inquiry focused on student learning

2. Grounded in context 
3. Methodologically sound

4. Conducted in partnership with students

5. Appropriately public.

\section{Inquiry focused on student learning}

In terms of student learning, Felten (2013) emphasizes that "learning should be understood broadly to include not only disciplinary knowledge or skill development, but also the cultivation of attitudes and habits connected to learning” (p. 122). This peer mentoring study focuses on the cultivation of one of those habits, namely, how students learn how to develop teaching presence through the collaborative use of digital technologies. Vaughan, Cleveland-Innes, and Garrison (2013) define teaching presence "as the effort and activity around the design, facilitation, and direction of cognitive and social processes in learning communities for the purpose of realizing personally meaningful and educationally worthwhile learning" (p. 2). The authors add that the responsibilities for teaching presence are distributed amongst all members of a learning community: "Teaching presence is enhanced when participants become more metacognitively aware and are encouraged to assume increasing responsibility and control for their learning" (Vaughan, et al, 2013, p. 13). Sharing the roles and responsibilities for teaching presence can potentially lead to the creation of a learning-centered environment in which everyone - not just the teacher — contributes to one another's growth and development.

\section{Grounded in context}

The second principle indicates the importance of grounding the study in context, here a teacher education program at a Canadian university. Table 2 provides a demographic profile of the first-year students in this program.

Table 2. First-year student demographics

\begin{tabular}{l|l}
\hline ITEM & PERCENTAGE/NUMBER \\
\hline Total number of students & $100 \%(96)$ \\
\hline Age & $\begin{array}{l}\text { Range: } 17-36 \\
\text { Average: } 19\end{array}$ \\
\hline Female & $88 \%(84)$ \\
\hline Living off campus with parents & $76 \%(73)$ \\
\hline Laptop computer & $100 \%(96)$ \\
\hline SMART phone & $98 \%(94)$ \\
\hline Tablet computer & $61 \%(58)$ \\
\hline
\end{tabular}

The majority of these first-year students are young women who are living at home with their parents, have just completed high school, and have been admitted to the program based on their grade point average (GPA) from provincial grade 12 diploma exams. In a pre-program survey, most of the students indicate minimal previous experience with the formative assessment practices of self-reflection and peer feedback, key competencies for $\mathrm{K}$ to 12 teachers in this province, according to the Alberta Government (2013). Thus, first-hand peer mentoring experience at university is crucial to their growth and development as future teachers. 


\section{Methodologically sound}

Our methods of investigation consisted of a mixture of quantitative (i.e., surveys) and qualitative (i.e., interviews) research methods that took place in two phases. The initial phase of our study focused on Professional Dimensions 1, the first course in the Bachelor of Education program. The course examines teaching and learning processes with reference to psychological, sociological, and philosophical influences in contemporary society. Students spend one morning a week in an elementary school placement where they are introduced to professional responsibilities, ethical behavior, language, and conduct.

We, Kayla and Naomi, completed this first-year course in the fall of 2012. We were both fortunate to receive support from the MRU institutional peer mentoring program for our course assignments. We thought that all first-year education students could benefit from peer support and thus, we approached our instructor Norm at the end of the semester with the idea of creating a peer mentoring program that would be supported through the use of collaborative technologies such as Google applications. During the winter 2013 semester, we co-designed an initial framework for such a program and completed institutional peer mentoring training for level 1 and 2 certificates. In the spring of 2013, our research team received institutional funding to study the implementation of the peer mentoring program during the fall 2013 semester.

For the pilot study, Kayla and Naomi invited all students and teachers involved in a Fall 2013 first-year Education course to be part of this research project, and a total of 63 students and 2 teachers participated (93\% student and 100\% teacher response rate). The project received institutional ethics approval.

The first iteration of this blended peer mentoring program involved Kayla and Naomi facilitating bi-weekly online discussions in the course's learning management system (Blackboard), responding and probing students' journal reflections in Google Docs, and providing synchronous tutorial sessions when needed via Skype. We both received a stipend from the internal research grant to provide this mentoring support to 68 first-year students ( 60 female and 8 male).

The first-year students completed a pre- and post-study anonymous online survey about their perceptions of the blended peer mentoring support. At the end of the semester, the faculty instructors responsible for the first-year course $(n=2)$ as well as Kayla and Naomi participated in thirty-minute faceto-face interviews regarding their perceptions of the advantages, challenges, and recommendations for peer mentorship initiative. These interviews were conducted and digitally recorded by Norm and transcribed by Kayla and Naomi.

A constant comparative approach was used to identify patterns, themes, and categories of analysis that "emerge out of the data rather than being imposed on them prior to data collection and analysis" (Patton, 1990, p. 390). We initially placed the data from the online surveys and interview transcriptions in a Google Doc. This digital data was then exported to the word cloud applications Wordle and Tagxedo in order to identify major themes related to the advantages, challenges, and recommendations for a blended peer mentoring approach in the first-year education course. Our research team then went back to the Google Doc and collaboratively categorized the data into subthemes that corresponded to the advantages, challenges, and recommendations for blended peer mentoring.

Based on the results of this pilot study, we then designed a second phase of the research project in the winter 2014 semester in collaboration with our faculty supervisor. This phase began with the development of a formal course assignment, which involved all second-year students in the process of learning how to mentor the first-year students. This assignment was embedded in a second-year 
educational technology course and focused on providing opportunities for second year students to learn how to design, facilitate, and assess peer mentoring support through the use of digital technologies.

This peer mentoring assignment was implemented in the fall 2014 semester and commenced with the second-year teacher candidates providing support to the first-year students with the initial creation of their journals in Google Docs and program portfolios in Google Sites (Figure 2). The journal serves as a space for students to record observations about how they are making connections between their course work and their field experience placements. The portfolio is used throughout the program by each of the students to document their growth and development in regards to the five program competency areas (planning, facilitation, assessment, classroom environment, professional roles and responsibilities).

\section{Figure 2. Second-year education students' peer mentoring first-year students}

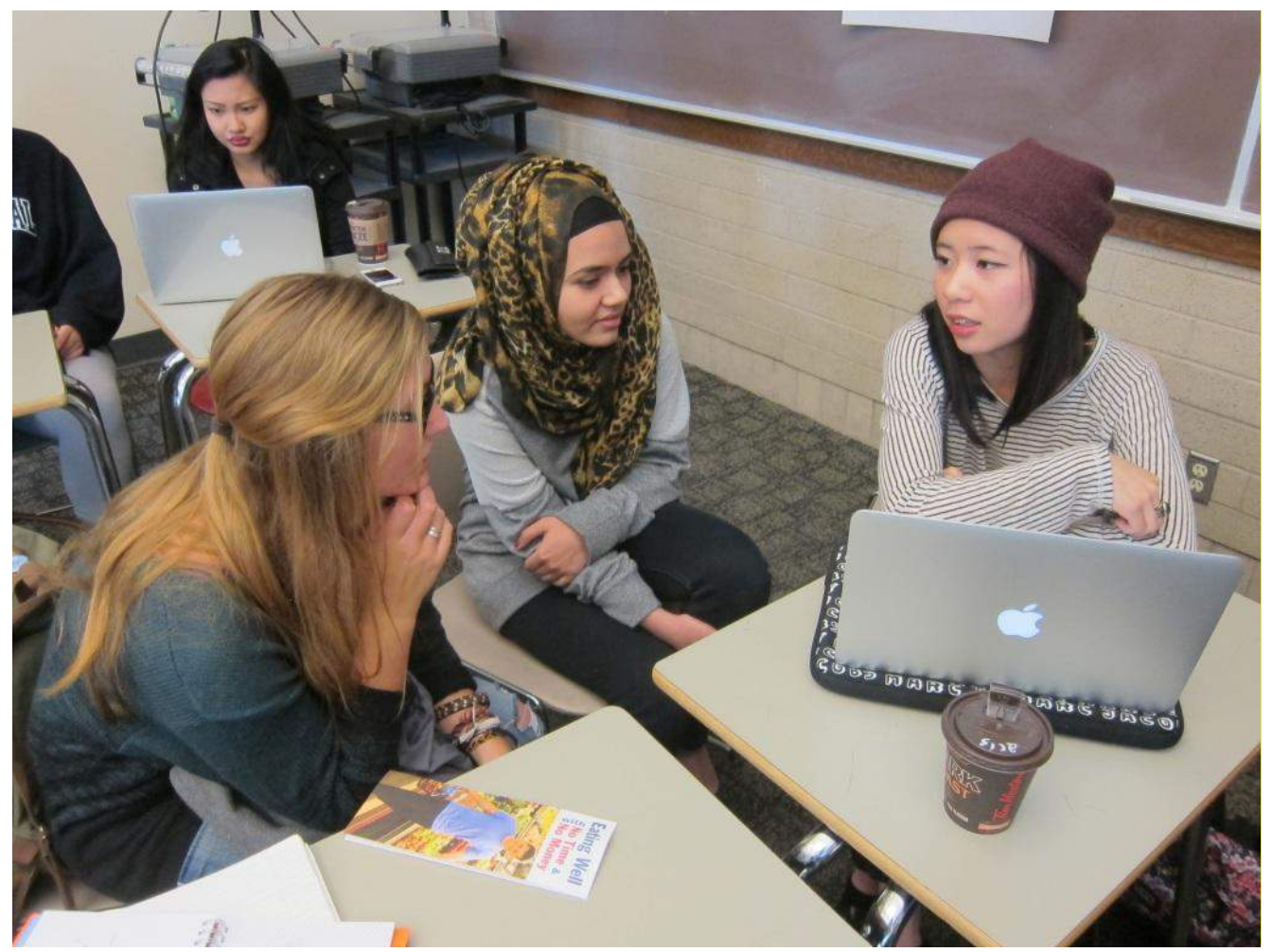

In the first-year course, the students have journal and portfolio checkpoints throughout the semester. The second-year students provided weekly online journal and portfolio support, and once a month they had face-to-face classroom meetings with the first-year students. Each of these face-to-face meetings took place in advance of a journal or portfolio checkpoint so that the first-year students could receive their mentoring feedback in person before submitting their work to the course instructor. The peer feedback was formative in nature (e.g., prompts for greater clarity and depth of understanding), while the course instructor feedback was summative (e.g., formal grade). There were 53 second year and 88 first-year education students involved in this phase of the research study.

For this second phase, each of the second-year students physically met with their first-year students at the end of the fall 2014 semester and collaboratively completed an assignment assessment rubric. The Mount Royal University teacher education program focuses on having students develop 
competencies in planning, facilitation, assessment, classroom environment, and professional roles and responsibilities. Kayla and Naomi were able to analyze and classify the student responses from each of the second-year students' completed assessment rubrics into four of these competency areas: facilitation, assessment, environment, and professional responsibilities.

\section{Conducted in partnership with students}

The importance of conducing SoTL research in partnership with students cannot be overstated. There have been numerous studies that have demonstrated that including students as partners in such work enhances student and faculty motivation, confidence, and sense of intellectual agency (Bovill, Cook-Sather, \& Felten, 2011; Cook-Sather, 2011; Mihans, Long, \& Felten, 2008; Werder \& Otis, 2010).

In addition, our study demonstrated to us that faculty members often perceive learning through a "course-based lens," while students view their learning from a broader program perspective (Vaughan, 2016). From a faculty perspective, Norm indicated that prior to this study, he had a very narrow view of the program, as he only had experience and insight about student learning within the specific courses that he taught. With regards to the student perspective, Kayla and Naomi commented that they immediately observed gaps between courses in the program but felt that they did not have the voice or authority to make suggestions or recommendations. Through this SoTL study, we believe that we have become learning partners by developing mutual respect and trust for each other's perspectives. We also believe student-faculty research partnerships are essential for teacher education programs.

\section{Appropriately public}

SoTL research is a reflective process of progressive problem solving led by individuals working with others in teams or as a part of a "community of inquiry" to improve the way they address issues and solve problems related to teaching and learning in higher education. This research approach should result in some practical outcome related to the lives or work of the participants, which in our case is the ability of pre-service education students to meaningfully provide feedback and support to each other (i.e., peer mentoring) in a blended format through the use of digital technologies.

During each stage of our SoTL study, we made sure to share our research findings with the students and faculty members of the teacher education program. Given the prevalence and popularity of peer mentoring programs, we also believe that the findings from our study demonstrate the importance of investigating and documenting their results, especially when they involve digital technologies, and particularly by engaging the very students who are serving as peer mentors.

\section{FINDINGS AND RECOMMENDATIONS}

The first and second iterations of this research study resulted in the following findings and recommendations, which we believe may be of value to other Faculties of Education.

\section{Pilot phase: Fall 2013}

The results for the first phase rely on our analysis of the online surveys that the first-year students completed at the beginning and end of the fall 2013 semester. The responses suggest numerous opportunities but also significant challenges to a blended peer mentoring approach in our first-year education course. In terms of benefits, we identified four key themes: new perspectives and expansion of ideas, positive and encouraging reinforcement, supportive connection with second-year students, and probing questions to think more deeply. 


\section{New perspectives and expansion of ideas}

From our analysis of the data, we found that the predominant benefit of peer mentoring was related to the development of new perspectives and the expansion of ideas $(13$ comments from 53 surveys). Most of our first-year students have limited experience with children in a classroom and thus draw on their own experiences as students rather than as teachers. They indicate that the peer mentor feedback in their Google Doc journals helped them begin to develop a teacher perspective and identity. For example, one participant noted, "The feedback from my peer mentor forced me to start thinking like a teacher and provided me with new perspectives about what I was experiencing in my field placement" (Survey participant 47). Another student said, "The feedback I have received from my peer mentor has allowed me to expand my thinking on what it means to become a teacher" (Survey participant 3 ).

\section{Positive and encouraging reinforcement}

The next most frequently cited benefit referred to the positive and encouraging nature of the peer mentoring feedback ( 11 comments from 53 surveys). The first field experience in our program can be stressful for some of the education students in our program due to their limited previous experiences with children in the classroom. They are often overwhelmed with the diversity of learning needs and the responsibility they have for each child in the classroom. They greatly appreciated the positive and encouraging reinforcement from their peer mentors, as can be seen in this statement by one student: "It was encouraging to receive feedback from someone who has experienced what I am experiencing now as teacher-candidate. The responses I received were positive and encouraging" (Survey response 23). Another student notes the particular importance of this positivity: "It was nice to be encouraged and complimented on my discussion board responses by the peer mentors, especially when I had a rough day in my field placement" (Survey participant 51).

\section{Supportive connection with second-year students}

Education students in previous studies indicate that they can feel isolated and alone in their field placements (Murray-Harvey, Slee, Lawson, Silins, Banfield, \& Russell, 1999). They can be too nervous to ask for support from their mentor teachers and faculty supervisors for fear of looking unprepared for the teaching profession. The first-year students in our survey also emphasized the importance of secondyear peer mentors providing them with non-judgmental support ( 10 comments from 53 surveys). The supportive connections from their peers who had gone before them is highlighted in this student's comment from the online survey. "I really appreciated the feedback from other students who had been in a similar position to me who could offer support to get through tough or thought provoking situations without being judgmental" (Survey participant 62). Another similarly notes the importance of the fact that "They were in the exact same situation as us last year, so they know what we are going through and can relate to us in a supportive manner" (Survey participant 15 ).

\section{Probing questions to think deeper}

The fourth major benefit that we identified from the survey data involved the peer mentors' ability to ask probing questions that made the first-year students to think more deeply about their field placement experiences ( 8 comments from 53 surveys). Another member of our MRU Education Department has previously observed that first-year students in our teacher education program often take a surface approach when they are journaling about their field placement experiences (Nickel, 2013). They simply describe the setting of a classroom rather than questioning and probing the learning and teaching transactions taking place within this environment. There were numerous comments about how 
important the peer mentors' questioning prompts were for promoting a deeper sense of reflection and thinking for the first-year students. One first-year student commented that "I always looked forward to reading their response. They often provided questions to allow me to think deeper. There was one time when they even provided quite a few of us with a link" (Survey response 39). Another student quote indicated, "I was able to go deeper into my thoughts. The peer mentor found great ways to phrase her questions to me to help me go further into what I was saying, and make more sense of what I was reflecting on" (Survey response 24).

The vast majority of first-year student feedback about the peer mentoring initiative was very positive. However, in the end-of-semester survey they identified three major issues about using digital technologies to support a blended peer mentoring approach: lack of email notification from the institution's learning management system (LMS) with regards to the peer mentors' online contributions, the impersonal nature of online peer mentoring, and the limited number of peer mentors.

\section{Lack of email notification}

The transition from high school to university is a challenge for many students, especially with respect to organizational and time management issues (Parker, Summerfeldt, Hogan, \& Majeski, 2004). These challenges can be particularly acute for first-year students in our teacher education program, as they are juggling not only multiple course assignments but also a field experience placement that requires additional time for preparation and commuting. Kayla and Naomi suggested that most of today's students are used to receiving email notifications or instant messages about contributions to Google Applications or Facebook discussion threads as time management reminders. Unfortunately, this feature is not available in Blackboard, and thus, several students commented about the lack of email notification when receiving feedback from their peer mentors ( 9 comments from 53 survey responses): "I didn't receive email notifications that my peer mentor commented on my Blackboard discussion board responses, so I often didn't view their responses" (Survey response 19). This technical glitch was particularly distressing for Kayla and Naomi, as they had put a tremendous amount of time and effort into providing peer feedback only to learn that it had not been accessed and read by many of the firstyear students. Although, this was another example of how this student-faculty research partnership provided them with an opportunity to see teaching from a professor's perspective.

A couple of students provided recommendations for overcoming this issue. For example, one student suggested that "the peer mentors could use Blackboard to send out a class wide email message once they had finished responding to our bi-weekly discussion forum postings" (Survey response 26). Kayla and Naomi also recommended that the faculty instructors should regularly remind students during class time to read and respond to their peer mentor's feedback.

\section{Impersonal nature of online peer mentoring}

Initially, this peer mentoring program was designed to be completely online to offer Kayla and Naomi maximum flexibility about when and how they could provide feedback to the first-year students, since they were the only two peer mentors in this phase. Several students commented about how they found the lack of face-to-face contact with their peer mentors to be challenging ( 9 comments from 53 surveys). One student in the end-of-semester online survey stated, "the more technology is around us the more the need for the human touch in education" (Survey response 2). Other students echoed this statement and indicated that the lack of physical contact with the peer mentors "was kind of impersonal, and not very effective, and for the first part of the semester I couldn't even figure out how to add them to my portfolio and journal” (Survey response 8). 
In terms of creating a more personal touch for this initiative, one student recommended that "the peer mentors could visit our classroom every couple of weeks to provide their summary and observations about the online discussion" (Survey response 7). In addition, Kayla and Naomi suggested that the faculty instructors provide more class time to discuss and debrief the journaling and portfolio activities.

\section{Limited number of peer mentors}

Kayla and Naomi need to be commended for spearheading the initial phase of our peer mentoring program, but the first-year students indicated that "only having two students mentoring two full classes was too much of a stretch. I can imagine it would be difficult to read and respond thoughtfully to 30+ people" (Survey response 43). Another student empathized, "I can imagine it was difficult for the girls to read and respond to ALL of the discussions. So, in the future, I think it would be beneficial to have more peer-mentors" (Survey participant 14).

In order to remedy this issue, numerous survey comments recommended increasing the number of peer mentors and providing them with specific tasks ( 19 comments from 53 surveys). One student suggested, "there could be peer mentors that are dedicated to responding to journals and making comments and the other mentors can respond to the discussion board questions" (Survey response 56).

Based on these recommendations, Kayla and Naomi then designed a second phase of the research project in collaboration with their faculty mentor Norm that was implemented in the fall 2014 semester.

\section{Second phase: Fall 2014}

A blended approach was implemented for the second phase of the peer mentoring program to address the challenges faced in the first phase of the research. All second-year students in the program are required to take an educational technology course with Norm as the instructor. Each student in this course was assigned either one or two first-year students to mentor for the fall 2014 semester. The peer mentoring support took place both online and face-to-face. At the end of the semester, each second-year student completed a peer mentoring assignment assessment rubric in collaboration with the first-ear students they had mentored. The second phase results are based on our analysis of the completed assessment rubrics. Our findings have been classified into four of the five competency areas for the B.Ed. program we outlined in the study context section: facilitation, assessment, environment, and professional responsibilities.

\section{Facilitation}

With regards to facilitating the learning process, the first-year students commented that the use of digital technologies such as Google Sites and Google Docs promoted constructive and engaging dialogue. For example, one participant noted, "my peer mentor sharing her portfolio really helped me to better understand what was expected of me and in my journal she gave me great examples with something to discuss and help me continue on my own" (Student assessment rubric 43). The secondyear peer mentors were also asked to provide clear explanations with rich language and examples. The following quote from a first-year student illustrates this type of peer feedback: "This is a great observation! I find that students have a hard time relating mathematics to their daily lives, as well. I often find them questioning when and where they will be using mathematics. Little do they know... Math is everywhere! It's important to get students to understand how they will use what they learn in the future" (First-year student journal 31). 
Initially, the second-year students commented that they found providing feedback in the online environment to be a challenge due to the lack of body language: "Without eye contact I was never sure if my first-year student really understood my comments and questions" (Student assessment rubric 61). Another student indicated that the face-to-face sessions were valuable for clarifying issues and concerns: "I really appreciated our monthly classroom meetings together. These helped us to get to know each other and I think it made my feedback seem more real for the first-year student I was working with" (Student assessment rubric 19).

In addition, at the beginning of the semester the second-year students received a two-hour peer mentoring workshop from our student learning services department who encouraged them to use question prompts to help analyze and respond to misconceptions, rather than to simply provide answers. One student commented, "his questions on my journal helped me to think more deeply about what I had written, they added to my learning as I went back and re-thought about what I was explaining" (Student assessment rubric 14). Another suggested that the use of question prompts helped advance higher levels of thinking: "her questions on our journals and portfolios prompted a deeper level of thinking which added to our discussions when we would meet face-to-face in our classroom" (Student assessment rubric 6).

\section{Assessment}

Globally, there has been an increased focus on formative assessment practices that provide students with ongoing rather than just summative feedback about their learning growth and development (OECD/CERI, 2008). One of the outcomes of this peer mentoring assignment was to have education students learn how to provide specific, timely, and constructive feedback to help their peers monitor their own learning. There were numerous comments in the assignment rubrics about how peer mentoring had begun to change the second-year students' mindset towards assessment, such as the following: "This assignment helped me begin to see that there is more to assessment than just getting a grade from an instructor. By providing feedback to a first year student I now understand the potential of formative assessment for growth and development" (Student assessment rubric 27). On the flip side, several second-year students commented about the challenge of providing formative assessment feedback, especially in the online environment: "I was already feeling overwhelmed with my own workload and I just couldn't find the time to respond to all the emails and requests from my first-year student" (Student assessment rubric 36).

\section{Environment}

Similar to assessment, there has been a growing trend in $\mathrm{K}$ to 12 education to focus on creating engaging classroom environments rather than on managing the classroom and the students (Parsons \& Taylor, 2011). The intent of this peer mentoring assignment was to provide both second- and first-year students with an opportunity to create a respectful and ethical learning community through online and face-to-face conversations that encouraged taking risks, building trust, embracing diversity, and increasing self-confidence. The majority of students commented in their assessment rubric that this process takes time and that it is often easier to develop a sense of trust in a face-to-face environment rather than online: "I always felt comfortable showing my peer mentor my portfolio and journal because I knew she would give me great feedback to further my learning. She was always respectful towards my work and to me as an individual and I always valued her opinion on my work and how it could be improved" (Student assessment rubric 49). 


\section{Professional responsibilities}

One of the goals the Mount Royal University teacher education program is to help the students develop their own professional learning network (PLN) that will support them in their future teaching practice. Recent studies have indicated that a significant number of new teachers leave the profession in their first five years due to feelings of isolation and lack of support (Clandinin, Schaefer, Long, Steeves, McKenzie-Robblee, Pinnegar, \& Wnuk, 2012). A number of second-year education students commented in the assessment rubric about how this assignment helped them "create professional and ethical relationships with the first-year students through interactions that were honest and with integrity. I learned how to provide good leadership to the best of my abilities, and I learned how to make decisions that reflected professional standards" (Student assessment rubric 53).

It is important to note that the findings from this SoTL research study are limited to one particular teacher education program at a Canadian university. However, we believe that education students in our program have similar characteristics to those in other faculties of education. Specifically, these students have a strong desire to become teachers but have limited experience with formative assessment practices such as self-reflection and peer feedback, which foster a sense of teaching rather than teacher presence. First-hand experience with peer mentoring can potentially help them develop a growth mindset (Dweck, 2007) with respect to an assessment 'for' learning approach, which they can then take forward into their future teaching practice. Thus, we believe our recommendations for a blended approach to peer mentoring may be of use to others involved in pre-service teacher education.

\section{FUTURE DIRECTIONS}

The majority of feedback from the education students who have been involved in this peer mentoring initiative has been very positive, especially with respect towards developing a teaching presence and formative assessment mindset. We have been asked by other faculty members in our B.Ed. program to help them develop peer mentoring assignments in each year of the program. Based on this support, we are now investigating the potential of creating a blended Mount Royal University Bachelor of Education Peer Teaching and Learning Circle that would involve peer mentoring activities in each of the four years (Figure 3).

\section{Figure 3. Mount Royal Bachelor of Education Peer Teaching and Learning Circle}

\section{MRU B.Ed. Peer Teaching and Learning Circle}

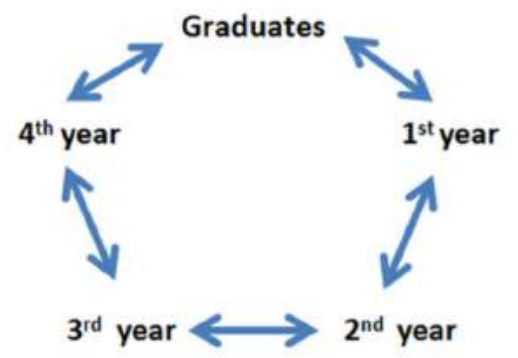

For example, through the formation of an Alumni Chapter and the use of collaborative technologies such as Google Applications (which are used by our local school boards), fourth-year students in our program could participate in an assignment that requires them to receive peer mentor support from graduates. Another assignment could be created that requires the third-year students to be 
supported by fourth-year peer mentors for their first practicum experience. And second-year students could have third year peer mentors for their semester-long inquiry-based learning projects.

One of the great benefits of peer support in a teacher education program is that both the mentor and mentee learn together to create a sense of teaching presence. This idea that "to teach is to learn twice" (Calvert, 1867) aligns with Alberta Education's (2014) goal that effective teachers know how to "collaborate to enhance teaching and learning." As we indicated in our introduction, this reciprocal teaching and learning approach is grounded in the Mãori concept of ako, which means both to teach and to learn (Alton-Lee, 2003). This notion of ako also encapsulates the potential of our team, Kayla and Naomi working as co-inquirers with their faculty member Norm in a SoTL research project. The mutual engagement that takes place through such a learning partnership not only enriches the students and faculty involved in such a research project but as documented in this study the research results (e.g., programmatic focus on peer mentoring) can also directly benefit other students and faculty members involved in higher education programs and courses (Healey, Flint \& Harrington, 2014).

In closing, our experience conducting this research study has reminded us of the African proverb that suggests "it takes a village to raise a child." We believe that a peer mentoring approach in a B.Ed. program not only provides first-hand teaching experience but also helps to create a "shift towards a 'welearning' conceptualization of education that will benefit us all” (Saint-Jacques, 2013, p.34).

Norman Vaughan is a Professor in the Department of Education at Mount Royal University in Calgary, Alberta, Canada.

Kayla Clampitt is a recent graduate of the B.Ed. program at Mount Royal University and she is now a full time teacher with Christ the Redeemer Catholic School District in Alberta, Canada.

Naomi Park is a recent graduate of the B.Ed. program at Mount Royal University and she is now a full time teacher with the Calgary Board of Education in Alberta, Canada.

\section{REFERENCES}

Alberta Education. (2014). Task force for teaching excellence.

Alberta Government. (2013). Teaching quality standard applicable to the provision of basic education in Alberta.

Alton-Lee, A. (2003). Quality teaching for diverse students in schooling: Best evidence synthesis. Wellington: Ministry of Education.

Astin, A. (1984). Student involvement: A developmental theory for higher education. Journal of College Student Personnel. July, 297-308.

Bovill, C., Cook-Sather, A., \& Felten, P. (2011). Students as co-creators of teaching approaches, course design, and curricula: Implications for academic developers. International Journal for Academic Development, 16, 133145.

Calvert, G. (1867). Some of the translated thoughts of Joseph Jobert. William V. Spencer: Boston.

Clandinin, D. J., Schaefer, L., Long, J. S., Steeves, P., McKenzie-Robblee, S., Pinnegar, E., \& Wnuk, S. (2012). Early career teacher attrition: Problems, possibilities, potentials. University of Alberta: Edmonton.

Chickering, A. W., \& Gamson, Z. F. (1999). Development and adaptations of the seven principles for good practice in undergraduate education. New Directions for Teaching \& Learning. 80, 75-82.

Collins, A., Brown, J. S., \& Holum, A. (1991). Cognitive apprenticeship: Making thinking visible. American Educator, Winter, 1-18.

Cook-Sather, A. (2011). Layered learning: Student consultants deepening classroom and life lessons. Educational Action Research, 19, 41-57.

Dweck, C. S. (2007). Mindset: The new psychology of success. Ballantine Books: New York, NY.

Felten, P. (2013). Principles of good practice in SoTL. Teaching \& Learning Inquiry: The ISSOTL Journal, 1(1), 121 125. 
Friesen, S. (2009). What did you do in school today? Teaching effectiveness: A framework and rubric. Canadian Education Association: Toronto.

Garrison, D. R., \& Vaughan, N. D. (2008). Blended learning in higher education. Jossey-Bass: San Francisco, CA.

Hattie, J. (2009). Visible learning: A synthesis of over 800 meta-analyses relating to achievement. New York: Routledge.

Healey M., Flint, A., \& Harrington, K. (2014). Engagement through partnership: Students as partners in learning and teaching in higher education. York: HE Academy

Heirdsfield, A. M., Walker, S., Walsh, K. M., \& Wilss, L. A. (2008). Peer mentoring for first year teacher education students: The mentors' experience. Mentoring \& Tutoring: Partnership in Learning 16(2), 109-124.

Kilgo, C. A., Sheets, J. E., \& Pascarella, E. T. (2013, November). Do high-impact practices actually have high-impact on student learning? Some initial findings. Paper presented at the annual conference of the Association for the Study of Higher Education, St. Louis, MO.

Le Cornu, R. (2007). Peer mentoring: Engaging pre-service teachers in mentoring one another. Mentoring \& Tutoring: Partnerships in Learning, 13 (3), 335-366

Murray-Harvey, R, Slee, P. T., Lawson, M. J., Silins, H., Banfield, G., \& Russell, A. (1999). Under stress: The concerns and coping strategies of teacher education students. Adelaide, Australia: University of South Australia.

Mihans, R., Long, D., \& Felten, P. (2008). Power and expertise: Student-faculty collaboration in course design and the scholarship of teaching and learning. International Journal for Scholarship of Teaching and Learning, 2, 1-9.

National Survey of Student Engagement (2011). Fostering student engagement campus wide_annual report 2011. Bloomington, IN: Center for Postsecondary Research.

Nickel, J. (2013). Self-assessment of professional growth through reflective portfolios. Phronesis, (2)1, 67-79.

Nora, A., \& Crisp. G. (2007). Mentoring students: Conceptualizing and validating the multi-dimensions of a support system. Journal of College Student Retention, 9, 337-356.

OECD/CERI. (2008). Assessment for learning: Formative assessment. OECD Publishing: Paris, France.

Pace, C. (1980). Measuring the quality of student effort. Current Issues in Higher Education. 2, 10-16.

Parker, J. D. A., Summerfeldt, L. J., Hogan, M. J., \& Majeski, S. A. (2004). Emotional intelligence and academic success: Examining the transition from high school to university. Personality and Individual Differences, $36(1), 163-172$.

Parsons, J., \& Taylor, L. (2011). Student engagement: What do we know and what should we do? Edmonton: University of Alberta.

Pascarella, E., \& Terenzini. P. (2005). How college affects students: A third decade of research ( $2^{\text {nd }}$ ed.). San Francisco: Jossey-Bass.

Patton, M. Q. (1990). Qualitative evaluation and research methods ( $2^{\text {nd }}$ ed.). Newbury Park, CA: Sage Publications.

Saint-Jacques, A. (2013). Effective teaching practices to foster vibrant communities of inquiry in synchronous online learning. In Z. Akyol, \& D. Garrison (Eds.), Educational communities of inquiry: Theoretical framework, research and practice (pp. 84-108). Hershey, PA: Information Science.

Vaughan, N. D. (2016). A blended approach to teacher education. In (S. Keengwe Ed.), Handbook of research on global issues in next-generation teacher education. Hershey, PA: IGI Global.

Vaughan, N. D., Cleveland-Innes, M., \& Garrison, D.R. (2013). Teaching in blended learning environments: Creating and sustaining communities of inquiry. Athabasca: Athabasca University Press.

Vaughan, N. D., LeBlanc, A., Zimmer, J., Naested, I., Nickel, J., Sikora, S., Sterenberg, G., \& O'Connor, K. (2013). To be or not to be: Student and faculty perceptions of engagement in a blended Bachelor of Education program. In C. Dziuban, C. Graham, \& A. G. Picciano (Eds.), Research perspectives in blended learning (pp. 104-121). New York, NY: Routledge, Taylor and Francis.

Vaughan, N. D., Nickle, T., Silovs, J., \& Zimmer, J. (2011). Moving to their own beat: Exploring how students use Web 2.0 technologies to support group work outside of class. Journal of Interactive Online Learning, 10, (3), 113127.

Vygotsky, L. S. (1978). Mind in society: The development of higher psychological processes. Cambridge, Massachusetts: Harvard University Press.

Werder, C., Thibou, S., \& Kaufer, B. (2012). Students as co-inquirers: A requisite threshold concept in educational development? Journal of Faculty Development, 26 (3), 34-38

Werder, C., \& Otis, M. (Eds.). (2010). Engaging students in the study of teaching and learning. Sterling, Vermont: Stylus.

78 Vaughan, N., Clampitt, K., \& Park, N. (2016). To teach is to learn twice: The power of peer mentoring. Teaching \& Learning Inquiry, 4(2). http://dx.doi.org/10.20343/teachlearninqu.4.2.7 


\section{Student Response to "To Teach is To Learn Twice: The Power of Peer Mentoring"}

From my own experiences, I have greatly benefitted from peer mentoring. It has helped me explore aspects of my own burgeoning educational practice. Although the list of benefits of peer mentoring is long, it does face some challenges.

When I read the article, I contemplated the multiple factors that impact the efficacy of peer mentorship. How does one anticipate those who are not ready or able to be effective peer mentors? Although the article discusses the benefits of peer mentoring, which I believe no one will dispute, it does raise the question of what it takes to be an effective peer mentor. When assigning peer mentoring as a task, there is a risk that it no longer encourages the development of a lifelong learning skill, and becomes another requirement to progress through a program. From my own experience, successful peer mentoring involves a significant time investment that requires exceptional time management skills. Similar perspectives were expressed by some of the students surveyed. Time management can be difficult to balance in an undergraduate program. Integrating peer mentoring into an education program may reduce the impact of time management related issues. However, making it mandatory for individuals to become peer mentors may result in unwilling participants, which could lead to poor mentoring experiences for the mentor and mentee. Negative peer mentoring experiences may negate the potential benefits of the relationship, which raises the question: can an individual create and maintain supportive connections when they feel they do not have time for those things themselves?

Technology was integrated into the peer mentoring process discussed in the article. This is an area where the benefits of using technology can be unclear. Although technology helps answer the logistical problems that arise with peer mentoring, such as time management, it tends to strip away the benefits that face-to-face interactions provide. This is implied throughout the article by the students surveyed. Two out of the three major challenges discussed in the article were technology focused. Does technology become a barrier or an effective tool for peer mentoring?

I believe peer mentoring is one of the core foundations of a successful pre-service teacher program. It is encouraging to see that the two student co-authors identified a need for a peer mentoring component. I believe that a student led approach to peer mentoring helps alleviate some of the anxieties undergraduate students may experience, especially those in a pre-service teacher program. Students naturally are drawn to mentoring one another, because they are both sharing a similar experience. This provides an advantageous opportunity over faculty led mentoring, because it is situated in a 'real time' environment, as opposed to someone who may have experiences that may seem dated or irrelevant. The big picture concept of a sustainable model that includes alumni is a promising idea; however, it is an ambitious undertaking due to the fact that peer mentoring is ultimately a voluntary process. I believe integrating a peer mentoring component that focuses on students lived experiences, and implemented 
by a balance of technology and face-to-face interactions, would be a beneficial addition to any preservice teacher program.

Steven Prediger is a fourth-year undergraduate at Mount Royal University, Calgary, Alberta, Canada, in the Bachelor of Education program.

\begin{abstract}
(c) (1)
Copyright for the content of articles published in Teaching \& Learning Inquiry resides with the authors, and copyright for the publication layout resides with the journal. These copyright holders have agreed that this article should be available on open access under a Creative Commons Attribution License 4.0 International (https://creativecommons.org/licenses/by/4.0). The only constraint on reproduction and distribution, and the only role for copyright in this domain, should be to give authors control over the integrity of their work and the right to be properly acknowledged and cited, and to cite Teaching \& Learning Inquiry as the original place of publication. Readers are free to share these materials — as long as appropriate credit is given, a link to the license is provided, and any changes are indicated.
\end{abstract}

